\title{
FEATURES OF ENDOCERVICAL ADENOCARCINOMA IN RELATION TO SQUAMOUS INTRAEPITHELIAL LESIONS AND SQUAMOUS CELL CARCINOMA OF THE UTERINE CERVIX
}

\author{
Aleksandar Živadinović1 , Aleksandra Petrić1,2, Biljana Živadinovićc ${ }^{3,4}$, Dane Krtinićc ${ }^{5,6}$, \\ Jelena Živadinović7, Radomir Živadinović1,2
}

\begin{abstract}
Cervical adenocarcinoma poses a huge diagnostic and therapeutic problem due to its endocervical localization and specific etiopathogenesis. Aims of the paper were: to establish characteristics of cervical adenocarcinoma in comparison to squamous cell type, to assess the validity of current diagnostic methods in cervical adenocarcinoma diagnostics, and to determine the best combination of diagnostic procedures that reduce the percentage of false negative results and demonstrate high sensitivity in cervical adenocarcinoma diagnostics. This was a prospective study comprising 180 patients operated for high-grade cervical intraepithelial neoplasia II and III, adenocarcinoma in situ and cervical carcinoma at the Clinic of Gyneacology and Obstetrics, University Clinical Center Niš.

The objective of our study was especially focused on patients with a histological diagnosis of adenocarcinoma. All the patients filled out a questionnaire prior to surgery and samples for human papilloma virus (HPV) testing were collected from all of them. HPV typing was performed at the Public Health Institute Niš, by using PCR method for detecting oncogenic HPV types and genotypes. HPV result was statistically significantly more commonly associated with adenocarcinoma. NILM finding was statistically significantly more commonly associated with AC pathohistological finding, while other cytological findings were statistically significantly more commonly associated with other PH results. Normal colposcopic finding was more commonly associated with AC pathohistological finding. Irregular bleeding finding in relation to defined groups of pathological finding is statistically significant and demonstrates medium strength of association. Irregular bleedings are statistically significantly more common in adenocarcinoma in comparison to severe forms of squamous changes.
\end{abstract}

Acta Medica Medianae 2021;60(4):16-22.

Key words: endocervical adenocarcinoma, diagnostics, HPV testing, colposcopic finding, irregular bleeding

\footnotetext{
${ }^{1}$ University Clinical Center Niš, Clinic of Gyneacology and

Obstetrics, Niš, Serbia

${ }^{2}$ University of Niš, Faculty of Medicine, Department of Gyneacology and Obstetrics, Niš, Serbia

${ }^{3}$ University Clinical Center Niš, Clinic of Neurology, Niš, Serbia ${ }^{4}$ University of Niš, Faculty of Medicine, Department of Neurology, Niš, Serbia

${ }^{5}$ University Clinical Center Niš, Clinic of Oncology, Niš, Serbia

${ }^{6}$ University of Niš, Faculty of Medicine, Department of Pharmacology and Toxicology, Niš, Serbia

${ }^{7}$ University Clinical Center Niš, Clinic of Anesthesiology and Intensive therapy, Niš, Serbia
}

Contact: Dane Krtinić

81 Dr Zoran Djindjić Blvd., 18000 Niš, Serbia

E-mail: dane.krtinic@medfak.ni.ac.rs

\section{Introduction}

Cervical adenocarcinoma poses a huge diagnostic and therapeutic problem due to its endocervical localization and specific etiopathogenesis. The incidence rate of this histological type of cervical cancer is lower compared to that of a squamous type, accounting for 5 to $15 \%$. Still, the latest epidemiological data reveal that the incidence rate of cervical adenocarcinoma has been increasing lately, especially in women under 40 years of age (1).

The incidence of squamous type of cervical carcinoma is significantly reduced due to exfoliative cytology and organized screening. On the other hand, since the sensitivity of cytology in detecting adenocarcinoma is low, the incidence rate of this histological type remains the same or is increasing.

The latest data of a Swedish trial in relation to the period of introducing cytology into cervical carcinoma screening programme reveal that the incidence rate of adenocarcinoma increased from $7 \%$ to 
$25.7 \%$. The greatest increase of adenocarcinoma incidence, three-fold higher, was recorded in younger patients (2).

The entity of endocervical adenocarcinoma is a heterogeneous group comprised of different histological types.

The current World Health Organization (WHO) classification of endocervical carcinoma was first published in 2014 as a novel classification. Usualtype endocervical adenocarcinoma is the most common subtype that is mostly HPV positive, less aggressive and with better prognosis in comparison to other subtypes.

The second most common subtype is mucinous adenocarcinoma, including gastric, intestinal, and signet-ring cell type. They are less commonly HPV positive, more aggressive and with poor prognosis. Among them, gastric type distinguishes as the most aggressive and HPV negative (3).

Unlike HPV+ usual-type adenocarcinoma with disease-free survival (DFS) of 74\%, in gastric type it is twice as low, with DFS of $38 \%$. Also, in comparison to usual-type, gastric type has a propensity for rapid extracervical spread. So, at the time of established diagnosis in $60 \%$ of cases the disease stage is higher than stage II, unlike usual-type where the disease is detected in stage I in over $80 \%$ of cases (4).

Besides gastric type, clear cell and mesonephroid adenocarcinoma distinguish in the HPV negative group.

Out of other adenocarcinoma subtypes, the following ones are noteworthy: villoglandular carcinoma, endometrioid carcinoma, clear-cell carcinoma, serous carcinoma, mesonephroid carcinoma, and some other less common types, such as mixed neuroendocrines.

Villoglandular type has a better prognosis, it is HPV positive, as most of mucinous carcinomas are, it is more common in younger patients. Serous and clear cell types demonstrate HPV positivity in about $30 \%$, whereas endometrial type is HPV positive in only $13 \%$ (5).

Aims of the paper were: to establish characteristics of cervical adenocarcinoma in comparison to squamous cell type, to assess the validity of current diagnostic methods (cytology, colposcopy, HPV typing) in cervical adenocarcinoma diagnostics, and to determine the best combination of diagnostic procedures that reduce the percentage of false negative results and demonstrate high sensitivity in cervical adenocarcinoma diagnostics.

\section{Patients and methods}

This was a prospective study comprising 180 patients operated for high-grade cervical intraepithelial neoplasia II and III, adenocarcinoma in situ, and cervical carcinoma at the Clinic of Gyneacology and Obstetrics, University Clinical Center Niš. The objective of our study was especially focused on patients with a histological diagnosis of adenocarcinoma. Our study enrolled 21 of them. The remaining
159 patients had a diagnosis of intraepithelial and invasive changes in the squamous epithelium.

All the patients filled out a questionnaire prior to surgery and samples for HPV testing were collected from all of them. Human papilloma virus typing was performed at the Public Health Institute in Niš, by using PCR method for detecting oncogenic HPV types and genotypes. All the results were statistically processed and presented in tables. A chi square test for independence $\left(\chi^{2}\right)$ was used for statistical analysis between categorical variables, and the Phi coefficient was used to measure the strength of association between variables. Statistically significant correlation was present in case of $p<0.05$.

\section{Results}

HPV- result was statistically significantly more commonly associated with AC (adenocarcinoma) pathohistological finding, for $\mathrm{p}<0.05$.

By comparing cytological and pathohistological results, it can be seen that NILM finding was statistically significantly more commonly associated with AC pathohistological finding, for $p<0.001$, while other cytological findings were statistically significantly more commonly associated with other $\mathrm{PH}$ results for $p<0.05$.

It is of statistical significance that normal colposcopic finding was more commonly associated with $A C$ pathohistological finding for $p<0.05$.

Irregular bleeding finding in relation to defined groups of pathological finding is statistically significant and demonstrates medium strength of association $\left(c^{2}=14.114 ; p<0.001\right.$; phi $\left.=-0.336\right)$. This analysis shows that irregular bleedings are statistically significantly more common in adenocarcinoma in comparison to more severe forms of squamous changes $(p<0.001)$.

Anamnestic data on positive family history of malignancy was statistically significantly more commonly associated with AC pathohistological finding for $p<0.001$.

\section{Discussion}

From Table 1 it can be seen that the greatest percentage of adenocarcinomas is HPV positive (71.40\% of them). On the other hand, if the percentage of HPV negative patients is analyzed, it can be observed that the percentage of these findings is higher in AC than in other squamous lesions (28.6:8\%). This difference is statistically significant.

Literature data reveal similar results. Most cervical adenocarcinomas are HPV positive, primarily HPV 18 and 45, in about 77\%, while HPV 16 positivity is about $15 \%$. Unlike adenocarcinoma, squamous cell type is most commonly HPV 16, 31, 33 positive (6). The reason for such a distribution should also be searched in diversity of a phylogenetic tree of the virus itself and in the type and origin of epithelium, that is in local viral tropism. In comparison to squamous cell carcinomas, the percentage of HPV positive adenocarcinomas is a bit lower. Statistically, slightly over $10 \%$ of endocervical 
adenocarcinomas is HPV negative (7). One of the reasons of such a distribution is in aforementioned heterogeneity of adenocarcinoma subtypes. Some of these subtypes are HPV negative, with different etiopathogenesis and risk factors.

Table 1. HPV test results in adenocarcinoma and other squamous lesions

\begin{tabular}{|c|c|c|c|c|}
\hline \multirow{2}{*}{$\mathrm{PH}$ result } & \multicolumn{2}{|c|}{ HPV positive-negative } & \multirow{2}{*}{ Total } & \multirow{2}{*}{$\mathrm{p}$} \\
\hline & HPV- & $\mathrm{HPV}+$ & & \\
\hline \multirow{2}{*}{$\mathrm{AC}$} & 6 & 15 & 21 & \multirow{4}{*}{0.004} \\
\hline & $28.60 \%$ & $71.40 \%$ & $100.00 \%$ & \\
\hline \multirow{2}{*}{ Others } & 12 & 138 & 150 & \\
\hline & $8.00 \%$ & $92.00 \%$ & $100.00 \%$ & \\
\hline Total & 18 & 153 & 171 & \\
\hline
\end{tabular}

Owing to understanding of these characteristics in relation to human papilloma virus infection, HPV test may serve as a good parameter in differential diagnosis of various cervical adenocarcinoma subtypes. Immunohistochemical markers, primarily p16 INK and CEA, as well as a range of a panel of other markers, predominantly $\mathrm{Ki}-67$, may also be useful in achieving better subtypes differentiation. HPV positive adenocarcinoma types, such as usualtype, are thus p16 INK positive, and differentiation marker CEA negative, unlike HPV negative ones, including gastric type, that are p16INK negative and CEA markedly positive. In contrast to gastric type, clear cell carcinoma is CEA negative, and that can also be helpful in making a differential diagnosis (8). Immunohistochemical marker p53 can be useful in differential diagnosis as well, since the values of this marker are most commonly elevated in HPV negative adenocarcinomas, such as gastric and intestinal ones, unlike usual HPV positive type with this marker being positive in only $3 \%$ of cases (9).

Cervical adenocarcinoma is difficult to diagnose. Standard diagnostic procedures, cytology and colposcopy, demonstrate the greatest percentage of false-negative results in this histological type of cervical carcinoma. Precancerous changes on the glandular epithelium are defined as adenocarcinoma in situ AIS, or glandular intraepithelial neoplasia GIN.
Since the epithelium is single-layered, differentiation of the stage and severity is difficult both to pathologist and cytologist. In classifying the results, a cytologist cannot rely on differentiation principle and epithelium thickness involvement, but his/her cytologic impression is based on the principle of severity of atypical cells and three-dimensional cell arrangement into specific pseudoglandular forms, acinus, nuclear protrusion, feathering, and alike. Such diagnostic parameters increase subjective expression of a cytologist, thus significantly decreasing validity in adenocarcinoma detection. On the other hand, a problem in cytological diagnostics is also cell collecting and harvesting, considering their fragility and easy loss of cytoplasm. A special problem is inadequate and insufficient sampling as a consequence of a cotton swab sampling. All these problems have resulted in epidemiological data indicating that cytological screening introduction has not significantly reduced the incidence of cervical adenocarcinomas (10).

Table 2 shows data on cytological findings of patients operated for $A C$ and squamous lesions. It can be seen from the Table, and it is also statistically confirmed, that a higher percentage of false-negative cytological results is noted in the group of patients with AC (85:13\%).

Table 2. Cytological finding in adenocarcinoma (AC) and other squamous lesions

\begin{tabular}{|c|c|c|c|c|c|}
\hline \multirow{2}{*}{$\mathrm{PH}$ results } & \multicolumn{4}{|c|}{ Cytological finding } & \multirow{2}{*}{$\mathrm{PH}$ result } \\
\hline & NILM & ASCUS, LSIL & HSIL, IC & Total & \\
\hline \multirow{2}{*}{$A C$} & 18 & 3 & 0 & 21 & \multirow{4}{*}{$<0.001$} \\
\hline & $85.70 \%$ & $14.30 \%$ & $0.00 \%$ & $100.00 \%$ & \\
\hline \multirow{2}{*}{ Others } & 21 & 69 & 69 & 159 & \\
\hline & $13.20 \%$ & $43.40 \%$ & $43.40 \%$ & $100.00 \%$ & \\
\hline Total & 39 & 72 & 69 & 180 & \\
\hline
\end{tabular}


Cytology sensitivity in detecting AIS and invasive adenocarcinoma found in literature data also shows lower values in the range from 44 to $63 \%$ (11).

In that sense, a growing number of studies points out the necessity of introducing HPV typing into cervical carcinoma screening. Unlike cytology, HPV test statistically significantly increases adenocarcinoma detecting sensitivity. The latest studies show that HPV screening primarily increases adenocarcinoma detection for more than a two-fold in relation to cytology (12).

HPV test may not only have a diagnostic, but also a predictive, prognostic value. So, a positive HPV 18 and 45 test, when cytology finding shows no changes, may be the first indicator of developing adenocarcinoma in these patients in the next 10 years (13).

Fortunately, adeno-changes are mostly associated with squamous ones, in about $70 \%$ of cases, so they are detected incidentally while testing squamous epithelial lesions. Cytological finding in adenochanges are suspicious of adenocarcinoma in only $25 \%$ of cases, while in $64 \%$ of cases a pathological cytological finding of adenocarcinoma done by a cytologist is described as a squamous lesion (14).

Colposcopic diagnostics is also a huge diagnostic problem in adenocarcinoma. Standard colposcopic images of AW epithelium, punctuation and mosaic are not necessarily present in adenochanges. Colposcopic image may show only enlargement of the cervical volume, blood vessels atypia, confluence and changes in papillae colour in the form of small islands on cylindrical epithelium. If the process is present in endocervical crypts, the crypt opening itself may be edematous in the form of a cuff around the gland opening, or as "skip" lesions with no colposcopic manifestations. The proximity of transformation (transitional) zone regarding clinical manifestations of adenochanges severity is not important, since a lesion may be focal, far from the transformation zone, but it can still be an advanced form of adenocarcinoma. Each endocervical crypt opening here may present a separate transformation zone. Transformation zones type 3 are a special problem since this transitional zone cannot be seen.

All the above mentioned problems in colposcopic screening of adeno-changes are illustrated in Table 3. Unlike squamous lesions where colposcopy reveals about $44 \%$ findings with less severe histological stage, in the case of AC that percentage is $71 \%$.

Anamnestic data on irregular vaginal bleeding may be a useful diagnostic parameter. Table 4 illustrates that more than $50 \%$ of patients with $A C$ had irregular bleeding as a symptom, and that was the reason they reported to their gyneacologists who established the diagnosis. Neoangiogenesis accompanies cervical carcinogenesis and is defined as the formation of new blood vessels that are fragile, without exactly the same components as normal blood vessels. This very fragility is one of the symptoms of irregular bleeding.

Table 3. Colposcopic finding in $\mathrm{AC}$ and other squamous lesions

\begin{tabular}{|c|c|c|c|c|}
\hline \multirow{2}{*}{$\mathrm{PH}$ result } & \multicolumn{3}{|c|}{ Colposcopy } & \multirow{2}{*}{$\mathrm{p}$} \\
\hline & Normal finding & Pathological finding & Total & \\
\hline \multirow{2}{*}{$A C$} & 15 & 6 & 21 & \multirow{4}{*}{0.03} \\
\hline & $71.40 \%$ & $28.60 \%$ & $100.00 \%$ & \\
\hline \multirow{2}{*}{ Others } & 74 & 85 & 159 & \\
\hline & $46.54 \%$ & $53.46 \%$ & $100.00 \%$ & \\
\hline Total & 89 & 91 & 180 & \\
\hline
\end{tabular}

Table 4. Anamnestic data on irregular bleeding in AC and squamous lesions

\begin{tabular}{|c|c|c||c||}
\cline { 2 - 4 } \multicolumn{1}{c|}{} & \multicolumn{2}{c|}{ Irregular bleeding } & \multirow{2}{*}{ Total } \\
\cline { 2 - 4 } \multicolumn{1}{c|}{} & no & yes & \\
\hline \hline \multirow{2}{*}{ AIS AC } & 9 & 12 & 21 \\
\cline { 2 - 4 } & $42.90 \%$ & $57.10 \%$ & $100.00 \%$ \\
\hline \multirow{2}{*}{ Others more severe } & 102 & 21 & 123 \\
\cline { 2 - 4 } & $82.90 \%$ & $17.10 \%$ & $100.00 \%$ \\
\hline Total & 111 & 33 & 144 \\
\hline
\end{tabular}


Sampling and histological diagnostics of adeno-changes can also be inadequate and problematic. Endocervical curettage of adeno-changes shows low sensitivity and may produce false-negative results. The problem is that a curette cannot harvest endocervical crypts in the cervical stroma. For these very reasons, the only diagnostic and therapeutic method in cytological and colposcopic examinations that appear suspicious for cervical adeno-changes is Loop Electrosurgical Excision or traditional conization.

Apart from etiopathogenesis and diagnostics, adenocarcinomas also differ from squamous lesions in risk factors and socio-epidemiological parameters. The number of sexual partners and smoking are significantly associated with squamous cell carcinoma, but not with adenocarcinoma. Adenocarcinoma risk factors are similar to endometrial carcinoma risk factors, such as the use of hormone therapy, obesity, and genetic factors. Table 5 shows that in case of $A C$, family history reveals genetic factor more commonly. A family history of gyneacologic malignancy was recorded in $71.4 \%$ of patients with $A C$ diagnosis.

Table 5. Anamnestic data on family history of malignancy in adenocarcinoma and other squamous lesions

\begin{tabular}{|c|c|c|c|c|}
\hline \multirow{2}{*}{$\mathrm{PH}$ finding } & \multicolumn{3}{|c|}{ Family history of malignancy } & \multirow{2}{*}{$\mathrm{p}$} \\
\hline & no & yes & Total & \\
\hline \multirow{2}{*}{$A C$} & 6 & 15 & 21 & \multirow{4}{*}{$<0.001$} \\
\hline & $28.60 \%$ & $71.40 \%$ & $100.00 \%$ & \\
\hline \multirow{2}{*}{ Others } & 114 & 45 & 159 & \\
\hline & $71.70 \%$ & $28.30 \%$ & $100.00 \%$ & \\
\hline Total & 120 & 60 & 180 & \\
\hline
\end{tabular}

\section{Conclusion}

According to all aforementioned facts, it can be said that endocervical adenocarcinomas present a heterogeneous group of tumors, having different etiopathogenesis, risk factors and clinical sympto- matology from squamous cell carcinomas. Despite the development of science and technology, these tumours are still an enigma that requires individual approach, clinical experience and further investigations of novel diagnostic procedures, immunohistochemical and genetic markers. 


\section{References}

1. Gustafsson L, Pontén J, Zack M, Adami HO. International incidence rates of invasive cervical cancer after introduction of cytological screening. Cancer Causes Control 1997;8(5):755-63.

[CrossRef] [PubMed]

2. Pettersson BF, Andersson $\mathrm{S}$, Hellman $\mathrm{K}$, Hellström AC. Invasive carcinoma of the uterine cervix associated with pregnancy: 90 years of experience. Cancer 2010; 116(10):2343-9. [CrossRef] [ PubMed]

3. Eide TJ. Cancer of the uterine cervix in Norway by histologic type, 1970-84. J Natl Cancer Inst 1987; 79(2):199-205. [PubMed]

4. Park KJ, Kiyokawa T, Soslow RA, Lamb CA, Oliva E, Zivanovic O, et al. Unusual endocervical adenocarcinomas: an immunohistochemical analysis with molecular detection of human papillomavirus. Am J Surg Pathol 2011;35(5):633-46. [CrossRef] [PubMed]

5. Tornesella ML, Buonaguro L, Giorgi-Rossi $P$, Buonaguro F. Viral and cellular biomarkers in the diagnosis of cervical intraepithelial neoplasia and cancer. Biomed Res Int 2013;2013:519619. [CrossRef] [PubMed]

6. Vizcaino AP, Moreno V, Bosch FX, Muñoz N, BarrosDios XM, Borras J, et al. International trends in incidence of cervical cancer: II. Squamous-cell carcinoma. Int J Cancer 2000;86(3):429-35.

[CrossRef] [PubMed]

7. Andersson $S$, Rylander $E$, Larsson $B$, Strand $A$, Silfversvärd $C$, Wilander $E$. The role of human papillomavirus in cervical adenocarcinoma carcinogenesis. Eur J Cancer 2001;37(2):246-50. [CrossRef] [PubMed]

8. Kojima A, Mikami $Y$, Sudo $T$, Yamaguchi S, Kusanagi $Y$, Ito $M$, et al. Gastric morphology and immunephenotype predict poor outcome in mucinous adenocarcinoma of the uterine cervix. Am J Surg Pathol 2007;31(5):664-72. [CrossRef] [PubMed]

9. Moll UM, Chalas E, Auguste M, Meaney D, Chumas J. Uterine papillary serous carcinoma evolves via a p53driven pathway. Hum Pathol 1996;27(12):1295-300. [CrossRef] [PubMed]

10. Etherington IJ, Luesley DM. Adenocarcinoma in situ of the cervix - controversies in diagnosis and treatment. J Low Genit Tract Dis 2001;5(2):94-8. [CrossRef] [PubMed]

11. Renshaw AA, Mody DR, Lozano RL, Volk EE, Walsh MK, Davey DD, et al. Detection of adenocarcinoma in situ of the cervix in Papanicolaou tests: Comparison of diagnostic accuracy with other high-grade lesions. Arch Pathol Lab Med 2004;128(2):153-7.

[CrossRef] [PubMed]

12. Gyllensten U, Lindell M, Gustafsson I, Wilander E. HPV test shows low sensitivity of Pap screen in older women. Lancet Oncol 2010;11(6):509-10. [CrossRef] [PubMed]

13. Dahlström LA, Ylitalo N, Sundström K, Palmgren J, Ploner A, Eloranta $S$, et al. Prospective study of human papillomavirus and risk of cervical adenocarcinoma. Int J Cancer 2010;127(8):1923-30.

[CrossRef] [PubMed]

14. Ronco G, Giorgi-Rossi P, Carozzi F, Confortini M, Dalla Palma P, Del Mistro A, et al. New Technologies for Cervical Cancer screening (NTCC) Working Group: Efficacy of human papillomavirus testing for the detection of invasive cervical cancers and cervical intraepithelial neoplasia: a randomised controlled trial. Lancet Oncol 2010;11(3):249-57. [CrossRef] [PubMed] 


\title{
SPECIFIČNOSTI ENDOCERVIKALNOG ADENOKARCINOMA U ODNOSU NA SKVAMOZNE INTRAEPITELNE LEZIJE I SKVAMOZNI KARCINOM GRLIĆA MATERICE
}

\author{
Aleksandar Živadinović1 , Aleksandra Petrić1,2, Biljana Živadinovićc,4, Dane Krtinić5,6, \\ Jelena Živadinovićn , Radomir Živadinović1,2
}

\begin{abstract}
${ }^{1}$ Univerzitetski klinički centar Niš, Klinika za ginekologiju i akušerstvo, Niš, Srbija
${ }^{2}$ Univerzitet u Nišu, Medicinski fakultet, Katedra za ginekologiju sa akušerstvom, Niš, Srbija

${ }^{3}$ Univerzitetski klinički centar Niš, Klinika za neurologiju, Niš, Srbija

${ }^{4}$ Univerzitet u Nišu, Medicinski fakultet, Katedra za neurologiju, Niš, Srbija

${ }^{5}$ Univerzitetski klinički centar Niš, Klinika za onkologiju, Niš, Srbija

GUniverzitet u Nišu, Medicinski fakultet, Katedra za farmakologiju sa toksikologijom, Niš, Srbija

${ }^{7}$ Univerzitetski klinički centar Niš, Klinika za anesteziju i intenzivnu terapiju, Niš, Srbija
\end{abstract}

Kontakt: Dane Krtinić

Bulevar dr Zorana Đinđića 81, 18000 Niš, Srbija

E-mail: dane.krtinic@medfak.ni.ac.rs

Adenokarcinom cerviksa (AC) predstavlja ogroman dijagnostički i terapijski problem zbog svoje endocervikalne lokalizacije i specifične etiopatogeneze. Ciljevi ovog rada bili su: utvrditi karakteristike cervikalnog adenokarcinoma u odnosu na tip skvamoznih ćelija, proceniti valjanost postojećih dijagnostičkih metoda u dijagnostici cervikalnog adenokarcinoma i utvrditi najbolju kombinaciju dijagnostičkih postupaka, koji smanjuju udeo lažno negativnih rezultata i pokazuju visoku osetljivost u dijagnostici adenokarcinoma cerviksa. Ovo je bilo prospektivno, istraživanje koje je obuhvatilo 180 bolesnica operisanih zbog cervikalne intraepitelne neoplazije II i III, adenokarcinoma in situ i karcinoma grlića maternice, na Klinici za ginekologiju i akušerstvo Univerzitetskog kliničkog centra Niš. Cilj istraživanja bio je posebno usmeren na bolesnice sa histološkom dijagnozom adenokarcinoma. Sve bolesnice popunjavale su upitnik pre operacije i od svih su prikupljeni uzorci za testiranje na humani papiloma virus (HPV). Tipizacija HPV-a izvedena je u Institutu za javno zdravlje Niš, PCR metodom za otkrivanje onkogenog tipa i genotipa HPV-a. Rezultat HPV-a statistički je značajno češće povezan sa adenokarcinomom. NILM nalaz statistički je značajno češće povezan s patohistološkim nalazom adenokarcinoma, dok su ostali citološki nalazi statistički značajno češće povezani s ostalim rezultatima PH. Normalni kolposkopski nalaz češće je povezan s patohistološkim nalazom AC. Iregularna krvarenja u odnosu na definisane grupe patoloških nalaza statistički su značajna i pokazuju srednju jačinu značajnosti. Iregularna krvarenja statistički su značajno češća u adenokarcinomu u poređenju sa teškim oblicima skvamoznih promena.

Acta Medica Medianae 2021;60(4):16-22.

Ključne reči: endocervikalni adenokarcinom, dijagnostika, HPV testiranje, kolposkopski nalaz, iregularno krvarenje 